Ks. Antoni Żurek

Uniwersytet Papieski Jana Pawła II w Krakowie

Wydział Teologiczny Sekcja w Tarnowie

\title{
SYNODY WCZESNOCHRZEŚCIJAŃSKIE
}

Wywodzący się z języka greckiego termin „synod” (synodos) ma w literaturze greckiej wieloznaczne znaczenie ${ }^{1}$. Euzebiusz z Cezarei w swojej Historii kościelnej tym terminem określał zgromadzenia niektórych gremiów w Kościele. Przede wszystkim chodziło mu o takie zgromadzenia w Kościele, na których obradowano i podejmowano decyzje. Ten sposób określania spotkań, zwłaszcza biskupów, przyjął się powszechnie, nie tylko w sferze języka greckiego. Od IV wieku termin synodus wszedł do języka łacińskiego, jako techniczne określenie zebrań biskupów, na których podejmuje się rozstrzygnięcia doktrynalne albo dyscyplinarne ${ }^{2}$.

W języku łacińskim terminem synonimicznym jest słowo concilium ${ }^{3}$. Po raz pierwszy w tym znaczeniu użył go Tertulian. W dziele $O$ poście przeciw psychikom uzasadniał istnienie w Kościele niektórych zwyczajów, wprowadzanych drogą rozporządzeń. W tym kontekście pisze, że w Kościele „w określonych miejscach odbywają się zgromadzenia [concilia] wszystkich Kościołów, na których [...] roztrząsa się poważne problemy"4. Jak widać, użył on tego terminu

1 Greckie synodos tłumaczyć można przez 'zebranie, zgromadzenie', a w sensie szerszym 'zjednoczenie, wspólnota wynikająca z czegoś, co łączy’; zob. Słownik grecko-polski, red. Z. Węclewski, Warszawa 1905, s. 619.

2 Por. Dokumenty synodów od 50 do 381 roku, „Źródła Myśli Teologicznej” [dalej: ŹMT] 37 (2006), s. 68.

3 Szerzej rozumie to Izydor z Sewilii, który thumaczy: „Synodum autem ex Graeco interpretari comitatum vel coetum"; Etymologia 6, 16, 11: PL 82,244.

${ }^{4}$ Tertulian, O poście przeciw psychikom 13, 6, tłum. E. Stanula, [w:] Tertulian, Wybór pism III, Warszawa 2007, s. 192. 
w dość szerokim znaczeniu, bo nie precyzuje, o jakie zgromadzenia chodzi i kto konkretnie brał w nich udział.

Te terminy przyjęły się w Kościele. W dokumentach łacińskich oba terminy: synodus i concilium, są dziś używane zamiennie na określenie specyficznych zgromadzeń biskupów. Od kilkudziesięciu lat to znaczenie się poszerza i można powiedzieć, że w ten sposób powraca się do pierwotnego ich wydźwięku. Niniejszy artykuł ma za cel przypomnienie pierwotnych znaczeń tych terminów.

\section{Synody „diecezjalne”}

Pierwsze wspólnoty albo gminy chrześcijan powstawały w sposób naturalny już w czasach apostolskich. Proces konstytuowania się takiej wspólnoty był nadzwyczaj prosty. Kiedy w danej miejscowości, czyli mieście - bo takie były wówczas realia - pojawiła się grupa wyznawców Chrystusa, zaczynali się organizować. Przede wszystkim ustanawiając sobie przełożonych. Mogło to następować na dwa sposoby. Z działalności św. Pawła wiemy, że często $\mathrm{w}$ zakładanych przez siebie wspólnotach sam ustanawiał przełożonego. W innych wspólnotach takich przełożonych wyłaniano w procedurze wyborczej. Tak ustanowieni przełożeni dobierali sobie spośród członków wspólnoty współpracowników i tak powstawała podstawowa struktura Kościoła, jaką była gmina, albo „Kościół w [...] Rzymie, Antiochii” czy też innym mieście.

Od końca I wieku na czele gminy stał biskup (episcopus), któremu pomagali „starsi” (presbiteros) wraz z diakonami. Z czasem takich urzędów współpracujących z biskupem przybywało. Ani co do liczby tych współpracowników, ani co do liczby stopni nie było odgórnych lub powszechnie obowiązujących dyrektyw. Zasada obowiązująca w tej sprawie była bardzo prosta. W każdej wspólnocie był jeden biskup, który stał na jej czele, oraz grupa pomagających mu prezbiterów i diakonów, tudzież innych pełniących określone funkcje służebne we wspólnocie. W zależności od liczebności wspólnoty, czasem od potrzeb samego biskupa, powoływano nowe osoby do pełnienia określonych zadań, a nawet tworzono nowe urzędy.

Wprawdzie tę podstawową jednostkę organizacyjną Kościoła nazywano gminą albo Kościołem w danym mieście i wielkościowo przypominała współczesną parafię, ale ze względu na jej strukturę bardziej odpowiednie jest jej porównanie do współczesnej diecezji. Wszak na jej czele stał biskup, miała 
wszystkie istotne elementy strukturalne i była niezależna w działaniu. Obejmowała ona całą daną miejscowość, niezależnie od jej wielkości i od liczebności chrześcijan. Diecezją w tym czasie zwano jednostkę administracji cywilnej. $\mathrm{Z}$ organizacją kościelną nie miała ona żadnego związku.

Władza biskupa była niekwestionowana i początkowo ograniczona tylko zasadami ewangelii. On decydował o sprawach bieżących wspólnoty, organizował życie religijne, czuwał nad przestrzeganiem zasad moralnych przez członków wspólnoty. Biskupowi pomagali „starsi”, czyli prezbiterzy, a w konkretnych sprawach inni członkowie wspólnoty. Istniały już różne urzędy, a w razie potrzeby powoływano nowe. Zważywszy na liczebność wspólnoty podległej biskupowi, spraw do rozwiązywania nie było za dużo. Oczywiście wraz ze wzrostem liczebności wspólnoty biskupowi przybywało pracy, a zwłaszcza spraw do rozstrzygnięcia. Przede wszystkim pojawiały się nowe problemy, wymagające nowego podejścia. Istniejące i znane wcześniej schematy okazywały się niewystarczające. Biskup stawał przed coraz to nowymi wyzwaniami, z którymi musiał sobie poradzić. Od niego oczekiwano decyzji i rozstrzygnięć.

Biskup nie był jednak sam. W sprawach mniejszej wagi, często wymagających delikatności, mógł liczyć na pomoc swoich najbliższych współpracowników, zwłaszcza prezbiterów. Z nimi konsultował rozwiazywanie problemów duszpasterskich. W rozwiązywaniu bieżących spraw wspólnoty duży udział mieli wszyscy jej członkowie. Organizacyjnie nie było to trudne w realizacji. Istniała zatem kolegialność realizowana na co dzień. W każdej chwili, gdy waga sprawy tego wymagała, biskup odwoływał się do całej wspólnoty. Przy jej udziale podejmował decyzje, które później realizowano. Były to przede wszystkim sprawy organizacyjne i dyscyplinarne.

Przykładem takiej kolegialności w sprawach organizacyjnych była elekcja przełożonych wspólnoty. Mogli w tym procesie uczestniczyć wszyscy członkowie wspólnoty pozostający w jedności ze swoją gminą. Euzebiusz z Cezarei relacjonuje jedną z takich elekcji: ,gdy wszyscy bracia zgromadzili się, aby wybrać kolejnego następcę na stolicy biskupiej, wielu z nich miało na uwadze licznych znakomitych i sławnych mężów"s. Jak widać, członkowie wspólnoty mieli nie tylko prawo wybierania, ale mogli zgłaszać swoich kandydatów

\footnotetext{
5 Euzebiusz z Cezarei, Historia kościelna VI 29, 3, tłum. A. Caba, ŹMT 70 (2013),
} s. 437 . 
na różne urzędy. Tak rozstrzygano sprawy dotyczące całej wspólnoty ${ }^{6}$. Biskup natomiast, do którego mimo wszystko należała najwyższa władza we wspólnocie, konsultował z całą wspólnotą albo przynajmniej z jej przedstawicielami (np. prezbiterami) istotne rozstrzygnięcia dotyczące wszystkich albo tylko poszczególnych członków wspólnoty. Niepotrzebne były do tego żadne formalne uregulowania w tym względzie i takich rzeczywiście nie było.

Były również nadzwyczajne sytuacje, kiedy biskup zwoływał albo całą wspólnotę, albo jej reprezentatywnych przedstawicieli dla rozstrzygnięcia spraw dużej wagi. Znamy tylko wybrane przykłady takich posunięć, więc nie sposób na ich podstawie przesądzać, kiedy pojawiła się taka praktyka i jaka była ich skala. Przykładem najbardziej znanym była afera, jaka wybuchła na początku lat 30. III wieku w Aleksandrii. Rzecz dotyczyła święceń udzielonych Orygenesowi przez biskupa Cezarei Palestyńskiej i za wiedzą biskupa Jerozolimy. Stało się tak dlatego, że biskupi ci chcieli, aby słynny już egzegeta głosił homilie w ich kościołach podczas pobytu w tych miastach. Fakt udzielenia święceń Orygenesowi wzbudził oburzenie biskupa Aleksandrii Demetriosa, którego Orygenes formalnie był „parafianinem”. Wtedy w Aleksandrii z inicjatywy biskupa Demetriosa „,doszło do tego, że przeciw Orygenesowi zwołano synod biskupów i niektórych kapłanów. Synod [...] postanowił usunąć Orygenesa z Aleksandrii tak, żeby nie mógł ani przebywać w mieście, ani prowadzić w nim działalności nauczycielskiej”" Działalność nauczycielska Orygenesa, o której w tym tekście mowa, polegała przede wszystkim na prowadzeniu przez niego słynnej Szkoły Aleksandryjskiej.

W sprawie Orygenesa zwołany więc został synod, w którym udział brali biskupi oraz prezbiterzy. Wprawdzie cytowany wyżej dokument mówi o udziale w synodzie biskupów, ale zważywszy na specyficzny ustrój Kościoła w Aleksandrii, synod ten możemy uważać za „diecezjalny”. Biskupi, o których mowa,

${ }^{6}$ Procedura powoływania na urzędy była nieco bardziej złożona, ale opierała się na zasadzie elekcji, szerzej zob. P. Christophe, L'élection des évêques dans l'Église latine au premier millénaire, Paris 2009, s. 15-28.

7 Focjusz, Biblioteka, t. 1, thum. O. Jurewicz, Warszawa 1986, 118.

8 W Aleksandrii biskupem z pełnymi tego słowa prawami był tylko patriarcha tego miasta. Natomiast na obrzeżach miasta, w małych miasteczkach czy nawet wsiach: „powoływano do pomocy biskupowi chorepiskopów lub periodeutów, a więc biskupów niższej rangi pozbawionych jedynie należącego się zwykłym biskupom prawa wyświęcania nowych członków kleru"; E. Wipszycka, Początki episkopatu monarchicznego 
pełnili funkcję podobną do tej, jaką pełnią dziś biskupi pomocniczy. Można zatem mówić o Aleksandrii jako jednej diecezji, w której funkcjonowali biskupi pomocniczy, ale też prezbiterzy stojący na czele wspólnot („,parafii”) w samym mieście. W sprawie Orygenesa obradował synod, którego uczestnikami byli właśnie rzeczeni „,biskupi i niektórzy kapłani”. Jedni i drudzy uczestniczyli na tych samych prawach, jakkolwiek głos decydujący należał do biskupa Demetriosa. Trudno osądzić, czy było to wydarzenie precedensowe, czy też praktyka znana wcześniej. Z pewnością nie istniały jeszcze żadne prawa, nawet lokalne, które by wymuszały ten tryb postępowania. Możemy się domyślać, że sprawa była tej wagi - choćby z uwagi na pozycję, jaką zajmował Orygenes - iż biskup chciał ją rozstrzygać na szerszym forum.

Przypadek z Orygenesem nie był całkiem wyjątkowy i odosobniony. W następnych dziesięcioleciach zdarzyło się jeszcze co najmniej kilka znanych nam podobnych przypadków. Przynajmniej o nich wiemy. Dotyczyły one prezbiterów, wobec których podejmowano kroki dyscyplinarne.

Jedna z takich spraw dotyczyła nauki głoszonej przez niejakiego Neposa w latach 50. III wieku'. Wystąpił przeciw niemu biskup Aleksandrii Dionizy zwany Wielkim (zm. ok. 265). Napisał stosowny traktat potępiający naukę Neposa, ale też „zwołał prezbiterów i nauczycieli braci mieszkających po wsiach”, aby publicznie przedyskutować dyskusyjne tezy ${ }^{10}$. Znów mamy do czynienia z „synodem” zwołanym przez biskupa Dionizego na podległym mu terenie. Uczestnikami byli duchowni zaangażowani w nauczanie. Synod obradował trzy dni. Nie podejmował uchwał dyscyplinarnych, a jedynie ustalił odpowiedź na poglądy głoszone przez Neposa i dał właściwą wykładnię nauki katolickiej.

Podobny charakter, choć jednocześnie z uchwaleniem sankcji dyscyplinarnych, miał synod zwołany w sprawie Ariusza, około 320 roku. Prezbiter ten wywołał skandal wśród wiernych swoim nauczaniem na temat Chrystusa. Gdy nie pomogły napomnienia miejscowego biskupa Aleksandra, zwołał on synod lokalny, na który przybyli podlegli mu biskupi i wraz z nimi potępiono

w Egipcie, [w:] Chrześcijaństwo u schyłku starożytności. Studia źródłoznawcze, t. 5, Kraków 2004, s. 293. Na temat praw chorepiskopów zob. Synod w Antiochii (341), k. 10, [w:] Dokumenty synodów od 50 do 381 roku, thum. S. Kalinkowski, Kraków 2006, 137*-138*.

9 Biskup Arsinoe, głosił chiliaizm.

${ }^{10}$ Szerzej zob. Euzebiusz z Cezarei, Historia kościelna VIII 24, 16. 
poglądy Ariusza, a jego samego trwającego w uporze, wykluczono z Kościoła w Aleksandrii ${ }^{11}$.

Znano również, przynajmniej na początku, inną formę ,synodowania” w ramach, jak się wydaje, „diecezji”. W II wieku, gdy pojawiały się coraz to inne sekty ,wierni [...] często i w wielu miejscowościach zbierali się [...] i nowe nauki poddawali gruntownemu badaniu, uznali je za bezbożne i potępili herezję. W ten sposób [tamci] zostali wykluczeni z tego kościoła i odłączeni od wspólnoty"12. Jak takie zgromadzenia wyglądały i jakie zapadały tam decyzje, można się tylko domyślać. W każdym razie zgromadzenie te miały charakter synodów, które dziś nazwalibyśmy diecezjalnymi. Zajmowały się one tymi sprawami wspólnoty, które nie wymagały pomocy z zewnątrz.

\section{Synody biskupów}

Jakkolwiek poszczególne wspólnoty chrześcijańskiej były autonomiczne i niezależne, to utrzymywały bliskie więzi z innymi, zwłaszcza sąsiednimi, i w wielu wymiarach współpracowały ze sobą. Te więzi i współpraca odbywały się głównie na poziomie zwierzchników wspólnot, czyli biskupów. Jedność biskupów wyrażała się zwłaszcza w trosce o zachowanie depozytu wiary. Z tych racji było rzeczą naturalną, że się ze sobą spotykali, konsultowali się w intrygujących ich sprawach, wzajemnie się wspierali, wymieniali między sobą opinie i wiadomości. Były to kontakty nieformalne, do których nie zobowiązywało żadne prawo. Świadectwem tych kontaktów są m.in. listy, jakie biskupi między sobą wymieniali. Tego typu relacje nawiązywano najczęściej w ramach regionu lub w obrębie państwowych jednostek administracyjnych, a takimi były: diecezja, prowincja. $\mathrm{W}$ tej sprawie nie obowiązywały żadne prawne ustalenia.

W II wieku zrodził się nowy zwyczaj, wynikły z potrzeby chwili. Pojawiły się bowiem problemy, których rozwiązanie przekraczało możliwości jednego biskupa. Taką sprawą było np. pojawienie się i działalność montanistów. Było to zjawisko dokuczliwe dla całego regionu, a nie tylko dla jednej wspólnoty. Wówczas ,zbierali się” - jak zapisze historyk - wierni wielu miejscowości, by razem

${ }^{11}$ Szerzej zob. J. Ożóg, Wstęp, [w:] św. Atanazy, Apologie, Warszawa 1979, s. 32; M. Simonetti, La crisi ariana nel IV secolo, Roma 1975, s. 29.

${ }^{12}$ Euzebiusz z Cezarei, Historia kościelna V 16, 10. 
radzić nad rozwiązaniem tej trudności ${ }^{13}$. Wprawdzie nie wiemy, kto dokładnie brał udział w tych wspólnych obradach, ale z praktyki wczesnochrześcijańskiej wiadomo, że wierni nigdy nie obradowali bez biskupów, więc obecność tych ostatnich na tych zebraniach nie podlega dyskusji.

Pierwsze znane nam zgromadzenia samych biskupów miały miejsce pod koniec II wieku. Bardzo trudnym do rozwiązania problemem była data świętowania Wielkanocy. „W tej sprawie odbywały się synody [synodoi] i zgromadzenia biskupów"14. Tak właśnie Euzebiusz po raz pierwszy nazwał zebranie biskupów. Jak wiemy z różnych źródeł historycznych, synody poświęcone ustaleniu daty świętowania Wielkanocy, o których pisał Euzebiusz, odbywały się w różnych miejscach i gromadziły biskupów z różnych regionów.

Pod koniec II wieku miał się odbyć również synod biskupów, na którym złożono z urzędu Noetosa ${ }^{15}$. To zdaje się pierwsze świadectwo władzy pozbawiania urzędu przez biskupów zgromadzonych na synodzie. Jak się dziś wydaje, decyzja podjęta na tym synodzie nie była kwestionowana i być może nie była precedensowa, choć nie mamy na to dowodów. Dla późniejszych synodów będzie to już naturalna prerogatywa. Kwestie dyscyplinarne, a wśród nich postępowania przeciw biskupom, staną się jedną z najczęściej procedowanych spraw na synodach.

W III wieku wzrosła częstotliwość zwoływania synodów biskupów. O ile wcześniej biskupi spotykali się $\mathrm{w}$ sprawach ważniejszej wagi, to z biegiem czasu stawały się one rutyną, zwłaszcza w niektórych regionach Kościoła. Pierwsze synody, o których mamy wiadomości, odbywały się na Wschodzie. Już na początku III wieku stały się one również praktyką Kościoła łacińskiego. W kilkadziesiąt lat później możemy już mówić o normalnej, choć jeszcze nie obowiązkowej, praktyce stosowanej w całym Kościele. Jednocześnie w tych synodach brała udział coraz większa liczba biskupów.

Zwoływanie i organizowanie synodów było regionalnie bardzo zróżnicowane. Zazwyczaj najważniejszą rolę w tym procesie ogrywali biskupi miast

\footnotetext{
${ }^{13}$ Euzebiusz z Cezarei, Historia kościelna V 16, 10.

${ }^{14}$ Euzebiusz z Cezarei, Historia kościelna V 24, 2.

${ }^{15}$ Hipolit, Przeciw Noetosowi, tłum. S. Kalinkowski, [w:] Trójca Święta, ŹMT 4 (1997), 90. W tekście jest mowa o prezbiterach, ale zdaniem krytyków wynika to tylko z jeszcze mało precyzyjnej terminologii w czasach powstawania traktatu; szerzej zob. G. De Vries, Il collegio dei vescowi nei sinodi prima di Nicea, „Humanitas” 19 (1964),
} s. 783. 
znaczących w danym regionie. Na Wschodzie byli to biskupi miast o starodawnych tradycjach chrześcijańskich: Antiochia, Efez, Cezarea, Aleksandria. $\mathrm{Na}$ Zachodzie początkowo była to Kartagina, Rzym. Później wiodącą rolę odgrywały coraz to nowsze miasta, których znaczenie zarówno administracyjne, jak też religijne rosło. Powoli wytwarzała się praktyka zwoływania synodów w tych samych miastach, co wiązało się z powstawaniem metropolii. Nie było to absolutne prawo, bo zdarzały się sytuacje, gdy synod zwoływano z jakieś okazji w mieście, gdzie nigdy wcześniej ani później podobnego wydarzenia nie było. Tak mogło być np. z okazji poświecenia nowego kościoła albo świętowania jakiejś rocznicy.

Jakkolwiek władza wszystkich biskupów była taka sama, to niektórzy z nich cieszyli się większym autorytetem. Z tej racji z ich zdaniem liczono się bardziej. Najczęściej autorytet danego biskupa miał swoje źródło w jego osobowości albo wiązał się z miejscem. Głos biskupów wspólnot większych albo z tradycjami liczył się bardziej. Długo decydowały o tym wyłącznie lokalne zwyczaje. Przykładem może być św. Cyprian, który wprawdzie pełnił swój urząd niespełna dziesięć lat, ale w tym czasie zwołał kilkanaście synodów, na których zapadały decyzje o bardzo dużym znaczeniu. Przez co najmniej kilkadziesiąt następnych lat synody kartagińskie nie miały takiego znaczenia.

Biskupi zgromadzeni na synodzie podejmowali uchwały, które z zasady miały ograniczony wpływ. Do ich przestrzegania zobowiązywali się biskupi biorący udział w takim synodzie. O podjętych uchwałach i rozwiązaniach powiadamiano jednak innych biskupów, którzy mogli przyjęte w ten sposób rozwiązania akceptować i wdrażać we wspólnotach przez siebie kierowanych. Taką drogą partykularne ustawodawstwo synodalne przyjmowało się w coraz to szerszym kręgu Kościołów lokalnych, stając się powoli prawem całego Kościoła. Nie oznaczało to jednak ani automatycznego powielania uchwał, ani nie przekreślało możliwości podejmowania autonomicznych decyzji w podobnych sprawach. Przestrzegano jednak zasady, że żaden synod nie powinien ingerować w uchwały innego synodu. Zasada ta było szczególnie widoczna w sprawach dyscyplinarnych. W praktyce oznaczało to, że decyzje dyscyplinarne, np. złożenie duchownego z urzędu, nie mogły być anulowane przez żaden inny synod. Nieco inaczej było w orzeczeniach dotyczących herezji. Mogło się zdarzyć, że jeden synod zakwestionował czyjąś prawowierność, a inny tej opinii nie podzielił. Tak było np. w III wieku w kwestii chrztu udzielonych 
przez heretyków, gdy synod w Kartaginie uznawał taki chrzest za nieważny, a synod w Rzymie uznawał jego ważność.

Synody odbywające się w pierwszych trzech stuleciach chrześcijaństwa $\mathrm{z}$ reguły reagowały na zaistniałą sytuację. Jeśli wynikła jakaś kontrowersja w nauczaniu albo wybuchł skandal spowodowany przez jakiegoś biskupa, wówczas biskupi danego regionu spotykali się, aby zaradzić sytuacji. Sprawy doktrynalne wyjaśniano i jeśli dopatrzono się błędu, wówczas błędny pogląd potępiano, a jego propagatorów wzywano do przyznania się do pomyłki i zaprzestania jej powtarzania. Gdy inkryminowany głosiciel zgadzał się z tą opinią, sprawa się kończyła. Jeśli nie, to uznawano go za heretyka i wykluczano z Kościoła. W przypadku osób piastujących jakiś urząd w Kościele wiązało się to oczywiście z usunięciem inkryminowanej osoby z powierzonego jej urzędu.

W przypadku kwestii dyscyplinarnych ustalano przede wszystkim słuszność stawianych zarzutów. Jeśli okazały się zasadne, winnego spotykała kara. Ponieważ te zarzuty dotyczyły przede wszystkim duchownych, więc kary polegały na pozbawieniu urzędów. W przypadkach bardzo drastycznych usuwano z Kościoła.

Poczynając od początku IV wieku synody ustalały zasady mające dopiero obowiązywać w Kościele ${ }^{16}$. To już nie było osądzanie poszczególnych przypadków, jakie zaistniały, ale określanie norm regulujących życie chrześcijan i działalność instytucji kościelnych. Bardzo interesującą nowością było ustalanie katalogu kar kościelnych. Pojawiły się zasady regulujące pokutę publiczną, a więc czasowe wykluczanie ze wspólnoty. Prawodawstwo synodalne stawało się coraz bardziej szczegółowe i obejmowało coraz większe obszary życia.

Synody zwoływali biskupi i przybywali na nie biskupi. Oni też podejmowali wiążące decyzje. Jednakowoż w tych synodach mogli uczestniczyć wierni oraz prezbiterzy. Oczywiście każdy z nich na ustalonych prawach. W aktach jednego z synodów w Kartaginie z połowy III wieku czytamy: „Gdy pierwszego września zebrało się w Kartaginie wielu biskupów z prowincji Afryki, Numidii, Mauretanii, oraz prezbiterzy i diakoni, w obecności większości ludu”17. Synod obradował nad kwestią ważności chrztu heretyków. Miał on formę debaty, w której głos zabierali jednak tylko biskupi. Pozostali w tym wypadku byli tylko

\footnotetext{
${ }^{16}$ Por. Synod w Elwira, ok. 306 roku.

${ }^{17}$ Synod w Kartaginie, 1.09.256, Wstęp, thum. J. Czuj, [w:] Dokumenty synodów od 50 do 381 roku, ŹMT 37, Kraków 2006, s. 27.
} 
obserwatorami i słuchaczami. Tak prawdopodobnie wyglądały inne synody, w których mogli uczestniczyć wierni. Ich udział ograniczał się prawdopodobnie do biernego przysłuchiwania się obradom. Komentatorzy przypuszczają, że niektóre zgromadzenia biskupów odbywały się w kościołach i wówczas wierni mogli być obecni.

Natomiast nieco inaczej mógł wyglądać udział prezbiterów. Przynajmniej na niektórych synodach. Na podstawie źródeł, którymi dysponujemy, możemy domyślać się, że prezbiterzy pełnili rolę ekspertów. Zapewne musieli mieć ku temu stosowne kwalifikacje. Występowali oni wtedy, gdy rozpatrywane były sprawy doktrynalne. Pierwszy taki przypadek relacjonuje Euzebiusz z Cezarei. Zgodnie z jego świadectwem bliżej nam nieznany biskup Beryllos (dzisiejszy Bejrut) zaniepokoił Kościół swoimi naukami. Zwołano synod, na którym odbyła się debata w obecności rzeczonego biskupa. Głos zabierali biskupi, ale „powołano Orygenesa, który się stawił i w rozmowie z tym człowiekiem wybadał przede wszystkim, jakie są jego poglądy. Gdy poznał jego przekonania, sprostował błędne wierzenia, przekonał go siłą swych dowodów, utwierdził w prawdziwej nauce i przywiódł z powrotem do dawnej prawowierności" ${ }^{\prime 18}$. Wprawdzie w tym wypadku nie doszło do potępienia nauki, bo biskup wycofał się z kontrowersyjnych poglądów, ale tym który mu w dyskusji błąd uświadomił był prezbiter Orygenes. Podobna sytuacja zaistniała dwadzieścia lat później, na synodzie oceniającym naukę biskupa Pawła z Samosaty. Tym, który miał za zadanie wykazania błędów tego biskupa, był prezbiter Malchion ${ }^{19}$. Sprawa zakończyła się wykluczeniem biskupa z Kościoła, bo oskarżony nie zmienił swojego zdania. Decyzję podjęli biskupi, ale błędną naukę zdemaskował ekspert, jakim był prezbiter Malchion. Nie miał on prawa podejmowania decyzji i nie brał udziału w samej procedurze pozbawiania urzędu, ale jego głos był wysłuchany, a co ważniejsze - wpłynął na stanowisko biskupów.

Pierwsze synody biskupów były wewnętrzną sprawą Kościoła i decyzje tam podejmowane były wiążące dla Kościoła i jego członków. Wyroki zapadające na tych synodach, zwłaszcza w sprawach doktrynalnych oraz dyscyplinarnych, dotyczyły członków Kościoła i Kościół mógł je wyegzekwować w swoim zakresie. Zdarzały się jednak sytuacje, w których z decyzjami synodu liczyły się władze świeckie, a nawet pomagały je wyegzekwować. Tak było jeszcze

\footnotetext{
${ }^{18}$ Euzebiusz z Cezarei, Historia kościelna VI 33, 2.

${ }^{19}$ Euzebiusz z Cezarei, Historia kościelna VII 29, 2.
} 
przed 313 rokiem, a więc w czasie, gdy ani Kościół, ani nawet chrześcijaństwo jako religia nie miały uznania ze strony państwa rzymskiego. Przykładem jest sprawa wspomnianego Pawła z Samosaty. Jak się okazało, nie pogodził się on z decyzją synodu pozbawiającą go urzędu. Wyrazem tego sprzeciwu była odmowa ze strony Pawła z Samosaty opuszczenia budynków należących do Kościoła. Wówczas zwrócono się do władz cywilnych i te opornego biskupa wyeksmitowały ${ }^{20}$.

W epoce pokonstantyńskiej taka procedura stała się normą, i to w zakresie o wiele szerszym. Przede wszystkim inicjatorem wielu synodów stał się cesarz. Zwyczaj taki zainicjował cesarz Konstantyn Wielki, zwołując najpierw synody lokalne w Rzymie (313) i Arles (314), a następnie synod powszechny w Nicei (325). Synody te zwoływał w celu rozwiązania konkretnych spraw, którymi mieli się zająć biskupi zaproszeni (albo nawet wezwani) na takie zgromadzenie. Praktyka ta przyjęła się bez sprzeciwu ze strony biskupów, co więcej - to oni „nie potrafiąc rozwiązać we własnym zakresie problemów piętrzących się przed Kościołem, zabiegali na dworze o interwencję władców, najczęściej wprost o zorganizowanie stosownego zgromadzenia biskupów”²1. Cesarze, następcy Konstantyna Wielkiego, zwołując synod, dobierali również jego uczestników, wyznaczali tematykę obrad, a co być może jeszcze ważniejsze, ponosili koszty organizacyjne, łącznie z opłaceniem kosztów podróży wezwanych biskupów ${ }^{22}$.

W tej sytuacji nie dziwi, że władze cywilne stawały się również egzekutorami uchwał, jakie podejmowano na synodach. Egzekwowały one postanowienia dyscyplinarne synodów biskupich w ten sposób, że jeśli zapadł wyrok usunięcia biskupa z urzędu, niezależnie od tego, czy było to ze względu na ortodoksję, czy też wykroczenia dyscyplinarne, służby państwowe dbały o jego eksmisję z miasta, w którym był biskupem. Tego typu wydarzeń, polegających na wywożeniu biskupów w odległe rejony Cesarstwa, było bardzo dużo zwłaszcza w IV wieku, w okresie sporów ariańskich.

Podobnie było w sprawach dotyczących również osób świeckich, zwłaszcza wtedy, gdy herezje i schizmy zostały uznane za przestępstwa ścigane przez

\footnotetext{
${ }^{20}$ Por. Euzebiusz z Cezarei, Historia kościelna VII 30, 19.

${ }^{21} \mathrm{~S}$. Bralewski, Imperatorzy późnego Cesarstwa Rzymskiego wobec zgromadzeń biskupów, Łódź 1997, s. 22.

${ }^{22}$ Zaproszeni biskupi mogli korzystać z tzw. poczty cesarskiej; szerzej zob. S. Bralewski, Imperatorzy późnego Cesarstwa ..., dz. cyt., s. 27.
} 
państwo. Synody określały, kto jest heretykiem, i co najwyżej usuwały winnych z Kościoła. Natomiast władze cywilne uznawały herezje w swoim prawodawstwie za przestępstwo i ustanawiały dla winnych kary, które później egzekwowały ${ }^{23}$.

\section{Synody ,ekumeniczne", czyli powszechne}

W IV wieku pojawił się nowy rodzaj synodów biskupich. Pierwszym z nich był synod w Nicei w 325 roku. Był to synod, który później po raz pierwszy w historii został nazwany „synodem ekumenicznym”, czyli powszechnym. W polskiej terminologii ten rodzaj synodów zwykło się nazywać soborami, w odróżnieniu od zwykłych synodów. Ten synod otworzył nowy rozdział w historii Kościoła, dając początek wcześniej nieznanej instytucji kościelnej, jakkolwiek w chwili jego zwołania nic nie zapowiadało, że będzie aż tak ważnym wydarzeniem, i nikt nie przewidywał jego historycznego znaczenia.

Cała historia miała początek dość charakterystyczny jak dla starożytnego Kościoła. Aleksandryjski prezbiter Ariusz wywołał wśród wiernych skandal swoim nauczaniem na temat Chrystusa. Mimo potępienia ze strony lokalnego synodu i biskupa Aleksandrii, pod którego władzą się znajdował, nie chciał zaprzestać głoszenia swoich poglądów. Co więcej, poskarżył się innym biskupom na złe traktowanie przez biskupa Aleksandrii, rozpoczynając w ten sposób wielki spór teologiczny na Bliskim Wschodzie. Ani wymiana listów między zainteresowanymi biskupami, ani lokalne synody nie były w stanie przywrócić spokoju i pogodzić zwaśnionych stron. W tej sytuacji do akcji wkroczył cesarz Konstantyn. Jak zapisał jego biograf: ,zwołał on synod powszechny i w pełnym szacunku liście zaprosił biskupów ze wszystkich prowincji, by niezwłocznie przybyli"24. Biskupi ,zaproszenie” przyjęli i stawili się w wyznaczonym przez cesarza czasie i miejscu. Było to 19 czerwca 325 roku w Nicei w Bitynii.

Zwołanie synodu w Nicei było precedensem w Kościele. Przede wszystkim zwoływał go cesarz Konstantyn, który wówczas nawet nie był jeszcze

${ }^{23}$ Szerzej zob. M. Stachura, Heretycy, schizmatycy i manichejczycy wobec cesarstwa rzymskiego (lata 324-428, wschodnia część Imperium), Kraków 2000, s. 27nn.

${ }^{24}$ Euzebiusz z Cezarei, Życie Konstantyna III 6. Sprawa zwołania tego synodu jest bardziej złożona, ale rzeczywiście jego inicjatorem i organizatorem był cesarz Konstantyn Wielki, szerzej zob. H. Pietras, Sobór Nicejski (325), Kraków 2013. 
ochrzczony. Zatem władza świecka, formalnie pogańska, wkraczała w sprawy wewnątrzkościelne. Wprawdzie cesarz był bardzo życzliwie usposobiony dla Kościoła i chrześcijaństwa, ale nikt ani żaden kościelny akt prawny nie uprawniły władcy do wtrącania się w wewnętrzne jego sprawy. Nic nam nawet nie wiadomo, by ktoś z biskupów zwracał się do niego z prośbą o zwołanie takiego synodu ${ }^{25}$. Charakterystyczne jest też to, że żaden z biskupów nie protestował przeciw decyzji cesarza. Widocznie nie widziano w tym żadnej niestosowności. Natomiast sam cesarz miał swoje powody, by zgromadzić wyznaczonych przez siebie biskupów i domagać się od nich rozwiązania kilku spraw ${ }^{26}$.

Do Nicei przybyło ponad 250 biskupów ${ }^{27}$. Wielu z nich z osobami towarzyszącymi, wśród których byli sekretarze i doradcy. Byli to przede wszystkim prezbiterzy i diakoni, ale niektóre źródła mówią nawet o świeckich. W obradach synodu i podejmowaniu decyzji brali udział tylko biskupi. Pozostali byli obserwatorami albo pełnili co najwyżej funkcje eksperckie i pomocnicze, jako doradcy biskupów.

Większość biskupów pochodziła z wschodniej części Kościoła. Kościół łaciński reprezentowało tylko kilkunastu biskupów. W skład delegacji łacińskiej wchodzili również przedstawiciele biskupa Rzymu. Reprezentowali go dwaj prezbiterzy. On sam usprawiedliwiał się podeszłym wiekiem i zniedołężnieniem. Powodów absencji innych biskupów Zachodu nie znamy ${ }^{28}$. Ich nieobecność nie została jednak źle odebrana i żadne restrykcje za to ich nie spotkały. Natomiast cesarz ,powiadomił [ich] o sprawach będących jego przedmiotem w napisa-

${ }^{25}$ Niektórzy próbują to tłumaczyć prerogatywami, jakie cesarz miał wobec religii pogańskich. Był on pontifex maximus wszystkich religii i kultów Imperium. W taki sam sposób cesarz Konstantyn miał potraktować chrześcijaństwo, które uznał za religio licita. Nie był to zresztą pierwszy synod zwołany przez Konstantyna Wielkiego. Wcześniej zwoływał on synody w Rzymie i w Arles poświęcone donatystom, ale one nie nabrały takiej rangi jak synod w Nicei.

${ }^{26}$ Szerzej zob. S. Bralewski, Imperatorzy późnego Cesarstwa..., dz. cyt., s. 24; H. Pietras, Sobór Nicejski (325), dz. cyt., s. 96nn.

${ }^{27}$ Szerzej na temat liczby uczestników Soboru w Nicei i wątpliwości na ten temat zob. S. Longosz, Liczba uczestników I Soboru Nicejskiego (325) w relacji Ojców Kościoła IV wieku, [w:] Ku prawdzie w miłości. Księga Pamiatkowa ks. bpa. J. Śrutwy, red. S. Koczwara, Lublin 2002, s. 71-86.

${ }^{28}$ Być może nawet nie zostali zaproszeni. 
nym przez siebie liście"29. Na obradach pojawili się za to biskupi spoza granic wschodnich Cesarstwa. Wymienia się biskupa z Persji, Kaukazu, a także biskupa pochodzenia gockiego. Można zatem zasadnie mówić o reprezentacji całego Kościoła. Jednak ten aspekt nie był specjalnie podkreślany w samych uchwałach.

Biskupi obradowali nad różnymi kwestiami, co widać po podjętych uchwałach. Natomiast sprawą dominującą okazała się kwestia ariańska, a więc doktrynalna. W obradach brał czynny udział cesarz Konstantyn Wielki, wpływając nie tylko na ich przebieg, ale również na ich rezultaty. Często powtarza się informację, że nawet przewodził obradom, a gdy nie mógł w nich uczestniczyć, zastępował go jeden z jego urzędników ${ }^{30}$.

Jako ciekawostkę można dodać, że na zakończenie obrad wszyscy uczestnicy otrzymali od cesarza podarunki. Nie była to jednak w żadnym wypadku nagroda za uczestnictwo w obradach. Łaskawość Konstantyna Wielkiego wynikała z nadzwyczajnej okoliczności towarzyszącej obradom synodu. Cesarz obrady synodalne połączył z obchodami dwudziestolecia swojego panowania. Biskupi zgromadzeni w Nicei uświetnili tym samym cesarskie uroczystości.

Uchwały „synodu ekumenicznego" zostały rozesłane wszystkim biskupom, którzy przyjmowali je bez sprzeciwu. Relatywnie szybko zostały zaakceptowane przez większość i stały się obowiązujące w całym Kościele. Historykom trudno wyjaśnić, z czego wynikała ta powaga synodu w Nicei. Tym bardziej że wkrótce zaczęły się odbywać podobne zgromadzenia biskupów, zwoływane na podobnych zasadach i w podobny sposób. Jedne z nich były zwoływane przez biskupów, inne przez cesarzy na prośbę biskupów albo z inicjatywy samych cesarzy. Na tych synodach podejmowano problemy doktrynalne i dyscyplinarne, podobne do tych rozpatrywanych w Nicei. Długo jednak żaden z nich nie uzyskał takiej rangi co nicejski ani nawet porównywalnej do niego.

Znamienne jednak, że zarówno Sobór Nicejski, jak też kilka późniejszych dopiero po upływie jakiegoś czasu od ich zakończenia zaczęto uważać za powszechny. Żaden z nich nie był „powszechnym” w chwili zwołania. Na dowód tego można przypomnieć, że dopiero po Chalcedonie (451) synod w Konstan-

${ }^{29}$ Euzebiusz z Cezarei, Życie Konstantyna III 16, thum. T. Wnętrzak, ŹMT 44 (2007), s. 177.

${ }^{30}$ Szczegółów obrad nie znamy, bo akta zaginęły, o ile istniały. Opieramy się na cząstkowych relacjach uczestników oraz późniejszych historyków; szerzej zob. H. Pietras, Sobór Nicejski (325), dz. cyt., s. 139-140. 
tynopolu (381) zaczęto nazywać „powszechnym”, czyli soborem. Wcześniej nawet jego uchwały doktrynalne pozostawały nieznane.

Proces uznawania synodu za powszechny lub partykularny inaczej przebiegał na Wschodzie, a inaczej na Zachodzie. W Kościele łacińskim mniej więcej od VI wieku tylko cztery wcześniejsze synody zostały uznane za powszechne, co w języku polskim określane jest mianem soboru, a inne pozostały tylko synodami lokalnymi, względnie partykularnymi, czyli synodami, nawet jeśli uchwały tych ostatnich były akceptowane przez cały Kościół ${ }^{31}$. Na dowód tego, że taka tradycja w VI wieku została już utrwalona przytacza się zwykle słowa św. Grzegorza Wielkiego, który w jednym ze swoich listów pisał: „Przyjmuję i czczę tak cztery księgi świętej Ewangelii, jak i cztery sobory, mianowicie: nicejski [...], konstantynopolitański [...], pierwszy efeski [...], chalcedoński" ${ }^{32}$. Proces uznawania dalszych synodów za sobory nie był jeszcze długo ustalony i dyskusje na ten temat trwały ${ }^{33}$. W Kościele łacińskim dopiero od XI wieku rozróżnienie na sobór i synod - używając polskiej terminologii - stało się klarowne ${ }^{34}$.

\section{$* * *$}

Instytucja synodów powstała i rozwijała się w Kościele można powiedzieć w sposób naturalny. Narodziła się spontanicznie już na samym początku istnienia wspólnot chrześcijańskich. Była wyrazem kolegialności najpierw w ramach jednej wspólnoty, a następnie na poziomie współpracy między sąsiednimi i coraz dalszymi wspólnotami. W tym drugim przypadku kolegialność dotyczyła przede wszystkim tylko biskupów stojących na czele poszczególnych wspólnot.

Bardzo intrygującą kwestią jest znalezienie odpowiedzi na pytanie o to, skąd wynikała władza synodu biskupów, czyli o jego podstawy teologiczne. Od sa-

${ }^{31}$ Szerzej zob. M. Fiedrowicz, Teologia ojców Kościoła. Podstawy wczesnochrześcijańskiej refleksji nad wiarą, tłum. W. Szymona, Kraków 2009, s. 326nn. Autor uważa, że ,powszechność” synodu zależała od recepcji jego uchwał i akceptacji ze strony Rzymu.

${ }^{32}$ Św. Grzegorz Wielki, List do patriarchów, [w:] św. Grzegorz Wielki, Listy, 1, 24 , thum. J. Czuj, Warszawa 1954, s. 45.

${ }^{33}$ Szerzej zob. M. Starowieyski, Sobory Kościoła niepodzielonego, Tarnów 1994, s. 154 .

${ }^{34}$ Zob. M. Fiedrowicz, Teologia ojców Kościoła ..., dz. cyt., s. 316. 
mego początku uchwały synodów były respektowane przez biskupów w nich uczestniczących. Kolegium biskupów zgromadzonych na synodzie uważało się za władne decydować w sprawach poszczególnych członków swego gremium. W miarę upływu czasu ta władza synodów rosła i miała coraz większy zakres. Nie ma świadectw, by ktoś próbował te prerogatywy synodów kwestionować. $\mathrm{Na}$ kolejnych synodach co najwyżej formalizowano i korygowano sposób działania tych gremiów. Pod koniec epoki patrystycznej autorytet synodów stał się na tyle oczywisty, że św. Augustyn nie musiał udowadniać, ale tylko przypomnieć zasadę rozstrzygania kwestii spornych w Kościele. Według niego proces ten wygląda w ten sposób, że zdanie jakiegoś biskupa może być skorygowane ,przez większy autorytet i większą uczoność innych biskupów, jak też przez [uchwały] synodalne. Same synody poszczególnych regionów i prowincji mają bez wątpienia mniejszy autorytet niż synody powszechne, reprezentujące cały świat chrześcijański” ${ }^{35}$. Taka hierarchia podejmowania decyzji w Kościele wydaje się już w V wieku naturalna i powszechnie akceptowana.

To powszechne uznanie dla tej formy kolegialności miało swoje uzasadnienie prawdopodobnie $\mathrm{w}$ tym, że biskupi czuli się sukcesorami kolegium apostolskiego, działającego razem pod przewodnictwem św. Piotra. Każdy z poszczególnych biskupów, niezależnie od tego na czele jakiej wspólnoty stał, był widocznie przeświadczony, że jest członkiem całego kolegium biskupów działającego w Kościele powszechnym, pod przewodem następcy św. Piotra. Wprawdzie zamanifestowanie tej wspólnoty w pełnym jej wymiarze ze względów praktycznych długo było niemożliwe, ale to nie przekreślało samej świadomości biskupów, którzy czuli, że tylko pozostając w łączności z całym kolegium, są następcami apostołów. Właśnie synody lokalne stanowiły namiastkę tej wspólnoty i dlatego czuły się uprawnione do działania w imię całego kolegium w tych sprawach, w których w grę wchodziło dobro Kościoła. Z czasem ta kolegialność stawała się coraz bardziej widoczna, by wreszcie dopełnić się w idei synodów powszechnych (czyli soborów).

W późniejszych stuleciach instytucja synodów przeszła pewne ewolucje i z czasem doczekała się nie tylko nowych podstaw formalnych oraz różnorodnych kształtów, ale również pełniejszych uzasadnień teologicznych. Sama jednak idea sięga początków Kościoła.

${ }^{35}$ Św. Augustyn, O chrzcie II 4.5, tłum. A. Żurek, ŹMT 38 (2006), s. 60. 